DOI: 10.2478/v10141-010-0005-1

\title{
Sociology of Sport Diagnosis in Brazil: to Consolidate a Field of Knowledge
}

\author{
Wanderley Marchi Júnior, Anna Letícia Padeski \\ Ferreira
}

Physical Education Department Federal University of Parana, Brazil

\begin{abstract}
\end{abstract}
Considering the expansion process which the sport sociology is facing in the Social Sciences and Physical Education fields, this study highlights the need to attribute to a specific area of knowledge a diagnosis treatment and the discussion of the sociological matters and conceptions emerging in sport. Also we included in this scenario the preliminary need detected in studies focused on the diagnosis of sport sociology in Brazil. The main goal of this research consists in the diagnosis of the papers that make reference to the sport sociology and to verify the consolidation, in the undergraduate and postgraduate area of this research field in Brazil. Specifically, we aim to localize the authors, their production, theoretical references and analysis models to codify a theoretical and methodological classification of the area, identifying conceptions, perspectives and study objects. We also attempt to make possible the structuring of an Excellence Centre in Sport Sociology studies in Brazil and the possible institutional exchange with Portuguese and Spanishspeaking countries, in Latin America. Part of this project is being accomplished by the creation of the Asociación Latinoamericana de Estudios Socioculturales Del Deporte - ALESDE. The methodology selected is a historic-descriptive research with an analytical-bibliographical character. The scope to this diagnosis will depend on the initial contacts with the productions, however we estimate a possible starting point in the 1950s. Through a preliminary study, we realized the mapping of two journals, one from Sociology and another from Physical Education, collecting data of the papers, such as: authors, theoretical approach, study objects and productions profile, from 1997 to 2007. As the results to this specific research we pointed out the absence of papers published in the Social Sciences journal. This may be the result of disputes and tensions of the academic field, considering issues as research legitimacy, prestige, and the superficiality of the papers submitted for publication, that does not attend the criteria of the referred journal. In the Physical Education journal the sport is a study object with insert, fact confirmed by the number of papers published. However, we noticed a large number of issues of this journal without any publication from Sport Sociology, which can be a symptom of a field in a consolidation process. Based on these indicatives we noticed that the papers we analyzed indicate a lack of a proper appropriation of the sociological theories to discuss, with the proper depth, the study object. These data allow us to elaborate a conception of the Sport Sociology as a field seeking its consolidation and autonomy in Sociology and in Physical Education. By this preliminary study and the wider research we present in this paper, we expect to fill a visible gap in the Sport 


\section{Background}

Sport nowadays is undoubtedly a social phenomenon that is located in an encouraging institutional space for in locus research of its various ways of manifestations (Bourdieu 1983, 1990), and within this logic, since the XIXth century Sociology of Sport has been constituting itself as a field of knowledge, studying its origin, its relations with the culture or even with religion (Pilz apud Vaz 1999).

In the historical passage of this research we can highlight Torstein Veblen's (1989) work, which, in his idle class theory, analyses sport as entertainment, strength recovery as well as dissipation of social tensions. Marcel Mauss (1902) broaches corporal techniques and the constitution of identities. Heinz Risse (1921), while acquiring his PhD degree under Alfred Weber's supervision, writes the first consistent work on the Sociology of Sport, carrying this very title, in which he analyzes the competitive sport based in a critical view of the industrial society model. Johan Huizinga's (1938) classical Homo Ludens, debates the cultural component in playful activities, specifically in the game.

Despite the fact that sociologists were directing their research at sports, the sport itself was academically located in a peripheral condition regarding the constitution of relevant objects of studies in the context of Social Sciences (Garrigou and Lacroix 2001). The sport, invariably, was treated in inferior levels of scientific representatively when compared to studies that focused on the material production as objects of study, the social classes and conflicts, for example. Elias and Dunning (1992) stated that the lack of relevance attributed to sports as objects of study is due to "heteronomic evaluations", in other words, evaluations on the facts according to its values of commitment or values of the scientific field, limiting the view to social phenomena approaches.

Notwithstanding this preliminary condition, other authors have come to study sports through a compensatory optics of the industrial society and the social alienation. We can indicate the studies of Scheler (1927), Jaspers (1931, 1955), Plessner (1952, 1956), Linde and Heinemann (1968). This fact confirms an account of Elias and Dunning (1992), in which the authors affirmed there is a monitoring on the part of the scholars, hence the heteronomic evaluations do not influence the perspective cast on sociological problems. Yet, the authors maintain that even so, sports still is not a recurrent theme in research.

This predilection for subjects considered relevant to the detriment of Sport can be based in the differentiation that Sociology has established between the serious and rational aspects of contemporary life, opposing the irrational and unconscious aspects, amongst which leisure would be included, and therefore, out of the range of relevant subjects of sociological analysis (Elias e Dunning 1992).

Over the years, and as the institutional growth and autonomy were conquered by the Social Sciences (Wallerstein 1996), sports strengthens its scientific legitimacy and begins to appear as an academic discipline as well as a central category in the field of the historical, anthropological and sociological analyses. Works contenting a critical reading of the sport and society inspired by the Frankfurt School evidence this process; amongst them we can highlight Lenk $(1972,1976)$, Rigauer (1969, 1979), Bohme, Gadow, Jesen, Pfister (1971), Gruneau (1983), Hargreaves (1982), Kirch (1986), Jean-Marie Brohm (1976, 1978), Berthaud (1974), Lüschen and Weis (1976).

In the Brazilian scenario, the agents involved with Sports Sociology research reveal subtle changes in the general picture of scientific productions and in the spaces reserved for debate of the 
subject. This is reinforced by the recent creation of the Sports Sociology work-group in the Associación Latinoamericana de Sociología (ALAS) ${ }^{1}$, the insertion of Sport in the Culture and Sociability prospect of the Sociology Post-graduation Program allocated at the Federal University of Paraná and the foundation of the Associación Latinoamericana de Estudios Socioculturales del Deporte (ALESDE) ${ }^{2}$, which intends to consolidate itself as a legitimate space for debate on Sociology of Sport.

In this brief historical identification of the Sociology of Sport, the object of study exceeds some stages and assumes a complexity that encloses innumerable perspectives of analysis and theoretical conceptions. By simply directing our focus to the possibilities of identification of the sport in relation to everyday life it is possible to enhance consciousness of this dimension: the social leisure, corporeity, social organizations, the cultural and ethical values, the social groups, the gender and age discriminations, and the environment. Or still, more specifically, daily problems of the sport: violence, doping, marketing, economy, the internationalization, among others (Bento and Marques 1989, Brohm 1993, Elias 1995, Bourdieu 1990, Dunning 1999, Coackley and Dunning 2002, Bracht 1997, Proni 2000, Helal, Soares and Lovisolo 2001, Betti 2001, Stigger 2002, Lucena and Proni 2002, Marchi Jr 2004).

In the specificity of sport, we can highlight moments where it was identified as an instrument of discipline and/or cathartics, form of social ascension and social distinction, responsible for the development of nationalism, ideological dispersive in the student movements, pro-elite or selected a parcel of the population that filled the requirements of physical performance in detriment of intellectual performance and, finally, as a spectacular and global merchandise (Marchi Jr 2004). In other words, the sport is able to reflect the inter-relations of the social, economical, political, cultural and ideological structure of the society (Elias 1980, 1990, 1993, 1995).

In the delimitation of this context, and summarily understanding the sport concept as a physical activity in constant development, built and determined as a social and cultural perspective and in a frank process of professionalization, merchandise development and spectacular process (Marchi Jr 2004, 2005), we highlight correlations, contradictions and considerations that emphasize the necessity of development and consolidation of a specific area of knowledge that focuses and supports the study of these questions, namely, the Sociology of Sports.

Examples of this complexity and possible relations between sports and society can be found in the historical passage of many sports and their sporting institutions in Brazil. In most cases, this passage had defined turning points and required transformations in order to become "viable sportive modalities" in the national and international context (Marchi Jr 2004, 2006).

Corroborating with our questioning, we can affirm that the Brazilian sport, since its first manifestations in the early XXth century (Lucena 2001), have not resisted the interdependency moments and hierarchic subordination in club administrations and, objectively, lived the most faithful expression of amateur principles, either revealed in its practice or through the entities responsible for its organization. We can evidence, by the testimonies of people who had intensely lived and/or studied sports and by the sources that registered the history of sporting modalities, that the amateur relation with the sport created a romantic idiosyncrasy in its development, dragging with it discriminations, abnegations, improvisations, limitations, restrictions and many other characteristics inherent to the practices that pass by this process (Marchi Jr 2004).

\footnotetext{
${ }^{1}$ Latin American Sociological Association.

${ }^{2}$ Latin American Association of Social and Cultural Studies of Sports.
} 
While this has been the tonic in most sports modalities in Brazil, it is not an exclusively national process $^{3}$, and some modalities had gone for the rupture of this state of facts. We assume that the sports started to gain professional contours that were capable to attract the media around its events and to canalize the spectacle process to the characteristic consumerist impulse of the modern capitalist society (Baudrillard 1970, Bourdieu 1983, 1990, 1997, Debord 1997).

In the face of this ongoing process of transformation of the practices and the sports management, we observe new interdependencies between administrative structures, social and political contexts and sportive modalities, in a favourable direction to the incursion of the professionalism in the sporting field. Regarding this historical and co-relational facts, other questionings emerged. We can highlight: How did the rupture occur with the so-called "romantic" model and the currently spectacular and merchandised configuration of the sport? Why had specific sporting modalities revealed these transitions differently to other modalities? Which were the selfinterests and the objects of dispute in the process of conceptual reorganization and remodelling of the sporting administrative structures? Along with the succession of the states of massive participation, professionalization and spectacular process of the sport, what kind of relation has been established between its supply and its demand? How and why can specific sporting modalities be considered as representations of the consumer society? What would be the relevance to a country encountering in its sports a representation, a symbol capable of divulging its "stage" of development?

In this questioning, we wish to emphasize that questions of this nature are constantly elaborated in the perspective to define the object of study and the contexts of analysis of the Sports Sociology. The condition of scientific production in this area elapses of this logic, which is capable of answering or, minimally, of elucidating directions to develop, research, study the answers in order to present a refined degree in the set of its analysis. This is the function that we expect and glimpse for the Sociology of Sport; nevertheless, given its "precocity", and under certain aspects, the supposed lack of a diagnosis of the production and the systematization of its scientific knowledge, the Sociology of Sport in Brazil is not consistently consolidated yet in the context of research lines in the scope of the post-graduates or still, in the thematic groups and work within the most representative Brazilian Physical Education congresses, collegiate, associations or institutions.

After briefly presenting this historical passage and this scenario, we affirm that Sociology of Sport is a scientific field of knowledge that must be, unconditionally, revisited and consolidated by researchers and scholars who objectify to debate issues regarding the complexity and the interrelational nature of this social phenomenon recognized as sport.

When previously briefing, we estimated that the deficiency of diagnostic studies in this area can be interpreted as a limiting factor for consistent scientific constructions or for consistent elaboration of theoretical-methodological references that subsidies the development and consolidation process of the Sociology of Sport. It is therefore insufficient to point out only the deficiencies and limitations. The relevancy and the requirements had been preliminarily stated, and now it is up to us to explore substantial advances and proposals in the sense of surpassing this state of art. On this direction, we believe that a diagnosis of the area involving the production, the definition of the study objects and

\footnotetext{
${ }^{3}$ About the British amateurism, Holt affirmed: "Perhaps the most central issue in the contemporary history of British sport has been the crisis and collapse of amateurism. This is the story of the decline and fall of a class of gentleman amateurs who ruled most sporting activities, only reluctantly recognizing and emancipating professionals in the 1960s and coming into conflict with the forces of commercialism and television." HOLT, Richard. Sport and History: the state of the subject in Britain. Stadion: International Journal of the History of Sport. XVIII, 2. Academia Verlag-Sankt Augustin, 1992, p. 286.
} 
used or elaborated theoretic-methodological compositions, can consist in a significant advance in the Physical Education and Sports Sociology scenario in the Brazilian and Latin American realm.

The justification of this research project echoes, as diagnosed preliminarily, the lack of diagnostic studies on the Sociology of Sport in Brazil. Empirically, we observe that the Sociology of Sport, since its emergence, has gone through transformations and alterations, reflected as much in the elaborations and theoretical incursions as in the absorption of new thematic of study.

Accordingly, we detected the possibility to investigate a set of studies that could generate a mapping of the Sports Sociology works developed in the Brazilian context; thus, in a second step, through this diagnosis, we visualize the scene in which this scientific field of knowledge was constituted, to identify the trends of the Brazilian Sociology of Sport and to consolidate its perspectives of studies in the face of the identified objects and trends. In this reasoning it also prudent to associate a required cautiously reading, deeper and considering a multi-disciplinary approach about the processes that affected and constituted sports as a great contemporary social phenomenon.

In this explanation, we can include the existence of a study group at the Federal University of Paraná - Centro de Pesquisas em Esporte, Lazer e Sociedade (CEPELS) ${ }^{4}$ - consolidated in the Conselho Nacional de Desenvolvimento Científico e Tecnológico $\mathrm{CNPq}^{5}$ group directory - as well as a research project approved by the Brazilian Sports Ministry's CEDES network, both of which turned to these issues. We believe that CEPELS/UFPR, along with CEDES network, will be able to contribute substantially to the development of this research and to consolidate this scientific area of knowledge.

\section{Materials and methods}

The development of this study had followed the theoretic-methodological guide lines of the Historical-Descriptive Research and the Bibliographical Research; in other words, the definition of a temporal period, a wide-ranging survey of primary sources, to make explicit the historical and social context where the object of study is located and the analysis of the collected material takes place. (Burke 1992, Chartier 1990). The methodological references of the Sociological Qualitative Research are added to these procedures (Becker 1997, Boudon 1998, Oliveira 1998, Ortiz 2002).

By following specifically the procedures defined by the authors cited above, the historical description will enclose a detailed bibliographical survey (primary sources) of the authors and its respective publications on Sociology of Sport from the 1950s to the current day. Subsequently, we will interpret and register its models and proposals of analysis in order to structuralize an introductory theoretical categorization of the Brazilian Sports Sociology, considering the definition of study objects and theoretical conceptions presented. For this research, in other words, at this phase of studies, that we intend to extend in a future project of post doctorate degree, we will work exclusively nationwide. In a second phase, after the conclusion of this project, we will study the international foundation and its contributions considering the possibilities of relations, interferences and interchanges.

We selected as methodological procedures of this study the content analysis, which will provide the necessary parameter for the implementation of this research. These procedures, according to Bardin (1977, p. 9) consist of a range of subtle methodological instruments and their constant improvement. However, despite this great adaptability, it is necessary to follow a controlled hermeneutics, founded in deduction.

\footnotetext{
${ }^{4}$ Sport, Leisure and Society Research Centre.

${ }^{5}$ National Counsel of Technological and Scientific Development.
} 
This unblinding task demands of the researcher a surveillance according to scientific criteria. We should not be taken in by the "transparency illusion" of the social facts, seeking to avoid the spontaneous comprehension. This "critical surveillance" demands a methodology and the instruments which are more useful as the researcher proximity degree increases (Bardin 1977, p. 29).

This methodological apparatus have two practical functions: one heuristic, that contributes to the exploratory attempt, increasing the possibility of a discovery, and a proof administration function, which formulates a hypothesis that serve as guidelines, maintaining the accuracy and scientific clarity (Bardin 1977, p. 29-30).

Posteriorly, we interpret and register its models proposals and analysis proposals through categories elaborated during the data selection and handling process, objectifying the structuring of an introductory theoretical classification of the Brazilian Sociology of Sport, considering the study objects definition and the theoretical concepts presented. To an analysis of these concepts, we consider it relevant to verify its appropriation by the researchers in the Brazilian scenario. This concept was chosen by stating the various forms of receptions and ways of using the Sociology theoretical basis to the Sport study. Thus are approached the various interpretations made by the reader and the interventions that occur in this process. Chartier (1998, apud. Catani et. al. 2001, p. 64) suggests that the appropriation comprehends a social story of the uses and interpretations of the texts and the fundamental determinations contained in the specific practices that produce this appropriation. In this way we should consider the conditions and the processes that lead the sense construction, conceiving that the ideas in the theory are not detached and disconnected of an historical path. So it is possible to see how the Sociology of Sport knowledge is being constituted.

To this research, or, to this study phase that we intend to enlarge in a future post-PhD project, we will work exclusively in the national perspective. In a second stage, and with the conclusion of this project, we will study the constitution and the international contributions considering the possibilities of relations, interferences and exchanges.

In synthesis, we limited our methodological procedures in a perspective that endorses a historical-descriptive and bibliographical research on the theoretical development of the sports sociology field of knowledge in Brazil.

Main objective: to consolidate, from the diagnosis of its production, Sociology of Sport as a research line in the Brazilian and Latin American Physical Education.

\section{Specific objectives:}

1. To identify authors and their respective production in Sociology of sport (amongst the diverse forms: books, chapters, papers, magazines, websites, etc.) initially, on national and Latin American scales.

2. To identify the production's main objects of study.

3. To systematize the main used and/or constructed analytical theoretic references of analysis.

4. To structure a Qualified Centre of studies and research on Sociology of Sport in Brazil, in undergraduate and post-graduate levels which provides availability of future cultural and scientific international interchanges. 


\section{Results}

In a preliminary study, "the State of the Art of the Brazilian Sociology of Sport: a mapping of the bibliographical production from 1997 to 2007", we carried through a mapping of the bibliographical production concerning to the Sociology of Sport in two periodicals: one in the Sociology academic field - Brazilian Journal of Social Sciences - and one in the Physical Education academic field - Brazilian Journal of Sports Sciences. Concomitantly to this mapping, we have performed an analysis of its scientific productions as well as proposed some inferences on the Brazilian Sociology of Sport scientific field (Ferreira 2009).

During the period investigated we could observe several issues related to the situation of the area previously explained. At first, we perceived that Sociology of Sport is a young area of study and that it is in a consolidation process in the Physical Education subject, since it posses institutional space, of publications and recognition, and in an emerging process in Sociology, since it was not established yet as a valid area of study and still requires institutional and periodical insertions (Ferreira 2009).

\section{Discussion}

We noticed that there does not seem to be any reticence about including Sociology of Sport's papers in the Physical Education periodicals, but there is a deficiency of appropriation ${ }^{6}$ of the sociological theories to read the phenomenon and a deepened analysis of the study object. These gaps would make the research unappealing for external scholars of this area (Ferreira 2009).

Yet in Sociology, the reticence is apparent, since no papers were published in the Social Sciences periodicals. It seems there is no interest for this thematic, and this indication is strengthened by the scarcity of research groups on the subject in the Sociology area. This can be the outcome of the academic field of Sociology's logic, where the dominant dictate the parameters of research that are considered relevant in that environment (Ferreira 2009).

Since the majority of the Sociologist-researchers are not interested in the study of the sport,who, then, are the scholars that have undertaken to do it? In this research we could evidence that most of the researchers are from the Physical Education area, therefore authors in which the appropriation process of the theories is in course, since they do not belong to the Sociological area. This defines the profile of the majority of the work as shallow, of superficial appropriation of the theories and with theory and social reality which are difficulty to relate (Ferreira 2009).

The analyzed papers had shown diverse unfolding of the subject of sport, they are mostly analytical and present an extensive theoretical referential for the construction of the context and discussion. Diverse concepts and parts of various theories, which restrict the author to carrying through a deeper approach of the object in focus and lead to a misuse of the theoretical matrix as an analysis tool (Ferreira 2009).

The application of theoretical bases was majorly superficial, which denotes that researchers do not possess a consistent appropriation of it, thus limiting its application. This also results from the choice of using many theoretical matrices, which makes this type of appropriation difficult. Thus, we could realize a deficiency of approaching theory to social reality in various papers (Ferreira 2009).

\footnotetext{
${ }^{6}$ Further information about the concept of appropriation in Bourdieu, P. O poder simbólico. Rio de Janeiro: Bertrand Brasil, 2007; Bourdieu, P. A leitura: uma prática cultural. In R. Chartier (org.). Práticas de leitura. São Paulo: Estação Liberdade, 2001.
} 
After concluding the dissertation, we perceived various possibilities for continuing the study. The chosen possibility for the present project of thesis is to continue the current study, applying a broader empirical universe and the possibility to make a comparative study with another field of the Sociology of Sport - the British or the New Zealander - in order to trace trends and possible directions of the area in Brazil (Ferreira 2009).

\section{Conclusions}

In developing this research project we expect to answer, fundamentally, the deficiency detected in diagnostic studies on the Sociology of Sport, moreover developing and consolidating a research line, in undergraduate and post-graduate levels.

Additional results are expected or potentially visualized with the implementation of this project; amongst them, we highlight: a) Possibly publishing a book on the Brazilian Sociology of Sport; b) Presenting preliminary results in national and international indexed journals; c) Presenting panels and papers in annals of the most renowned and theme-relevant Congresses; d) Structuring a Qualified Centre of qualification of human resources in research on the Sociology of Sport; e) Carrying out international interchanges with other Educational Institutions related to the studies of Sociology of Sport; and f) Possibly extending and developing the unfolding issues of this research in a postdoctorate perspective.

\section{REFERENCES}

Bardin, L. (1977). Análise de Conteúdo. Lisboa: Edições 70.

Baudrillard, J. (1970). A Sociedade de Consumo. Lisboa: Edições 70.

Becker, H.S. (1997). Métodos de Pesquisa em Ciências Sociais. $3^{a}$ ed. São Paulo: Hucitec.

Bento, J., Marques, A. (1989). Desporto, Ética e Sociedade. Portugal: Universidade do Porto.

Betti, M. (2001). Educação Física e Sociologia: novas e velhas questões no contexto brasileiro. In Y.M. Carvalho de, K. Rúbio (Eds). Educação Física e Ciências Humanas. São Paulo: Hucitec.

Boudon, R. (1998). Os Métodos em Sociologia. Lisboa: Rolim.

Bourdieu, P. (1990). Coisas ditas. São Paulo: Brasiliense.

Bourdieu, P. (1983). Questões de sociologia. Rio de Janeiro: Marco Zero.

Bourdieu, P. (1997). Sobre a televisão. Rio de Janeiro: Zahar.

Bracht, V. (1997). Sociologia Crítica do Esporte: uma introdução. Vitória: UFES.

Brohm, J-M. (org.) (1993). Materiales de sociologia del deporte. Madrid: las ediciones de la piqueta.

Brohm, J-M. (1976). Sociologie Politique du Sport. Paris: Ed. Dlarge.

Burke, P. (org.) (1992). A Escrita da História: novas perspectivas. São Paulo: Unesp.

Catani, A., Catani, D. Pereira, G. (2001). As apropriações da obra de Pierre Bourdieu na campo educacional brasileiro, através de periódicos da área. Revista Brasileira de Educação, Anped, n.17, mai-ago. Retrieved from http://www.anped.org.br/rbe/rbedigital Acesso em 16 dez. 2008.

Chartier, R. (1990). A história cultural: entre práticas e representações. Rio de Janeiro: Bertrand Brasil.

Coackley, J., Dunning, E. (2002). Handbook of sports studies. London: Sage.

Debord, G. (1997). A Sociedade do Espetáculo. Rio de Janeiro: Contraponto.

Dunning, E. (1999). Sport Matters: sociological studies of sport, violence and civilization. London: Routledge.

Elias, N. (1980). Introdução à sociologia. São Paulo: Martins Fontes. 
Elias, N. (1990). O Processo Civilizador: 2: Formação do Estado e Civilização. Rio de Janeiro: Jorge Zahar.

Elias, N. (1993). O Processo Civilizador: 1: Uma história dos costumes. Rio de Janeiro: Jorge Zahar.

Elias, N., Dunning, E. (1995). Deporte y ocio en el proceso de la civilización. México: Fondo de Cultura Económica.

Elias, N., Dunning, E. (1992). A busca da excitação. Lisboa: Difel.

Ferrando, M.G. (1990). Aspectos sociales del deporte: uma reflexión sociológica. Madrid: Alianza.

Ferreira, A.L. Padeski. (2009). O Estado da Arte da Sociologia do Esporte no Brasil: um mapeamento da produção bibliográfica de 1997 a 2007, p. 269. Dissertação (Mestrado em Sociologia) - Setor de Ciências Humanas, Letras e Artes. Curitiba: Universidade Federal do Paraná.

Garrigou, A., Lacroix, B. (2001). Norbert Elias: a política e a história. São Paulo: Perspectiva.

Helal, R., Soares, A.J., Lovisolo, H. (2001). A invenção do país do futebol: mídia, raça e idolatria. Rio de Janeiro: Mauad.

Holt, R. (1992). Sport and History: the state of the subject in Britain. Stadion: International Journal of the History of Sport. XVIII, 2. Academia Verlag-Sankt Augustin.

Lucena, R. de Figueiredo. (2001). O esporte na cidade. Campinas: Autores Associados.

Lüschen, G., Weis, K. (1976). Sociologia del deporte. Valladolid: Miñon.

Magnane, G. (1969). Sociologia do Esporte. S. Paulo: Perspectiva.

Marchi Jr., W. (2004). “Sacando” o Voleibol. São Paulo: Hucitec; Ijuí: Unijuí.

Marchi Jr., W. (2006). Como é possível ser esportivo e sociológico? In A. Gebara, L.A. Pilatti (org.). Ensaios sobre história e sociologia nos esportes. Jundiaí: Fontoura.

Marchi Jr., W. (2005). Desporto. In F.J. González, P.E. Fensterseifer (org.). Dicionário Crítico da Educação Física. Ijuí: Unijuí.

Oliveira, P. de Salles (org.) (1998). Metodologia das Ciências Humanas. São Paulo: Hucitec.

Ortiz, R. (2002). As Ciências Sociais e o Trabalho Intelectual. São Paulo: Olho d'água.

Pilz, G.A. (1999). In A.F. Vaz. Sociologia do Esporte na Alemanha. Revista do Centro de Pesquisa e Documentação de História Contemporânea do Brasil, FGV, n. 23.

Proni, M., Lucena, R. (orgs.) (2002). Esporte, História e Sociedade. Campinas: Autores Associados.

Proni, M.W. (2000). A metamorfose do futebol. Campinas: IE.

Stigger, M.P. (2002). Esporte, lazer e estilo de vida: um estudo etnográfico. Campinas: Autores Associados.

Vaungrand, H. (1999). Sociologies du sport: théorie des champs et théorie critique. Paris: Harmattan.

Wallerstein, I. (1996). Para abrir as Ciências Sociais. São Paulo: Cortez. 